\title{
Toward A Model For The Acceptance Of Internet Banking In An Emerging Market
}

\author{
TOAN LE DUC ${ }^{1}$, PHU NGUYEN HUU ${ }^{2 *}$, LOAN PHAM THI BE ${ }^{3}$, HUNG PHAN TRAN MINH ${ }^{3}$ \\ ${ }^{1}$ Socio - Eco Research Institute, Graduate School, Duy Tan University \\ 03 Quang Trung Street, DaNang City, 550000, VIETNAM. \\ ${ }^{2}$ Board of Provost, Graduate School, Duy Tan University \\ 03 Quang Trung Street, DaNang City, 550000, Vietnam, nhphunq@duytan.edu.vn \\ ${ }^{3}$ University of Economics-The University of Danang, VIETNAM. \\ 71 Ngu Hanh Son Street, DaNang City, 550000, VIETNAM.
}

\begin{abstract}
Vietnam has the concrete socio - eco characteristics as low General Domestic Product (GDP) per capita, not high people's education level, undeveloped information infrastructure and long - standing consumers' habit of cash, etc...However, given its enormous market opportunities and intensified competition, Vietnam is mentioned as a fast - growing emerging market offering great chances to advance practices in accepting developed services. The study's aim is to find factors affecting to customer's intention in using internet banking of Vietnamese, which results propose recommendations to managers of motivating customer intension as well as improving internet banking services. The study integrates the technology acceptance model and theory of planned behavior with an additional construct called customer service to be suitable with conditions of Vietnam. The findings support that the intention to adopt internet banking in Vietnam emerging economy are predicted by 6 factors, namely perceived ease to use, perceived usefulness, customer service, customer satisfaction, subjective norm and perceived behavior control, wherein subjective norm, perceived behavior control and customer satisfaction were the strong - influencing indicators of adopting internet banking. The study's results show that the proposed model has a good explanatory power and confirms its robustness in predicting customers' intentions to adopt Internet banking. The study broadens and deepens understandings of factors contributing to the development of internet banking, especially for an emerging country such as Vietnam.
\end{abstract}

Keywords: Intention to adopt internet banking; Vietnam emerging economy; Partial Least Square (PLS); Mediation Analysis; Importance Performance Matrix Analysis (IPMA).

Received: September 24, 2020. Revised: March 23, 2021. Accepted: April 6, 2021. Published: April 14, 2021.

\section{Introduction}

\subsection{Banking Technology}

The information technology progress benefit banks to create banking services which are more competitive, more efficient and more user friendly (Akinci et al., 2004; Kannabiran and Narayan, 2005). The provided interpretation information is vitally needed for bank decision makers to understand how to maintain balance between security and reliability of their financial system (Meshref, 2020). Internet banking has widely used for activities such as online shopping, online bill payments, online auctions, stock trading, and so on (Blut, 2016; Bryman, 2007). Internet technology improves e-banking qualities, for instance, fast transactions, security, cost reduction and convenience.

Internet banking has become a well - developed phenomenon in the developed countries and also setting its foothold in developing countries such as Vietnam in the early of this decade. Recently, most of the Vietnam banks are selecting internet banking as a delivery channel and an efficient tool to operate business activities.

\subsection{Internet banking in Vietnam emerging economy}

Vietnamese commercial banks launched internet banking in the 2010s. The internet users in Vietnam has rapidly raised over time. On December, 2000, there were about 200,000 internet users, this number reached about 64 million on June, 2018 ${ }^{(1)}$.(about $66.3 \%$ of the total Vietnam population)

However, in year 2017 the size of the e-commerce market in Vietnam has only reached about $\$ 4$ billion, which accounts for $2-3 \%$ of the total retail value of $\operatorname{goods}^{(2)}$, and Ministry of Industry and Trade of Vietnam predicted that Vietnam's e-commerce will 
only earn $\$ 10$ billion by $2020^{(3)}$. That is the very big limitation in developing e-commerce in Vietnam.

In Vietnam, only about $40 \%$ of commercial bank customers use internet banking in their transactions. It is clear that the adoption of internet banking services is still very low among customers of commercial banks in Vietnam. There are still large cluster of clients who prefer the traditional ways of banking, the reasons for which can be attributed to the following:

- Using cash habit: Vietnamese use cash for most of their expenses at the traditional market and supermarkets. Besides, they use cash for taxes, bills and fees such as electricity, water, telephone fees .etc.. In contrast to other markets in the world, the direct purchase of goods in Vietnam is much easier in person than online. In addition, customers don't believe on the quality of goods sold via online shopping, on social media and websites.

- Worrying about risks: Customers are concerned about the safety and reliability of online banking services, worried about risks such as hacker attacks, financial fraud, and unpredictable events.

- Purpose of using internet banking: Vietnamese usually open accounts at banks with a main purpose of sending and borrowing money. Most of them do not have much access to online baking because they think the service is complicated and difficult for them to use. Besides, many services in Vietnam are not part of the e-commerce market.

- Most hotels and restaurants do not offer online booking.

-The lack of IT infrastructure: It is necessary to have a large amount of capital to invest IT infrastructure. The lack of investment capital has led the low development of banking services such as wireless internet does not have wide coverage, card payment terminals and ATM machines are usually located only in densely populated areas.

-The shortage of human resources: Banks need many staffs who have the skills to use IT effectively, have the habit of working electronically and also be highly proficient in banking because they no longer work directly with customers.

Until to now, there is only few of quality studies about intention to adopt internet banking in Vietnam. Therefore, the present paper may give an insight about the factors that influences the customer's intention to adopt internet banking.

\section{Review of literature and hypothesis development}

\subsection{TAM, TRA and TPB}

Several theory models on human behavior have suggested as TRA (Theory of reasoned action) of Ajzen \& Fishbein (1980), TAM (Technology Acceptance Model) of Davis (1989), and TPB (Theory of Planned Behavior) of Ajzen (1991).

With TRA (Ajzen and Fishbein, 1980) stated that behavior can be predicted from intentions corresponding directly to that behavior. TRA has been used to explain the adoption of IC and has been successfully applied to predict behavior and intention in a variety of subjective areas; but TRA is a general theory; it does not specify the beliefs that are operative for particular behavior (Davis et al., 1989).

In term of TAM, Davis (1989) opined that the two important factors influence their decision about how and when they will use it, those are Perceived usefulness (PU) and Perceived ease-of-use (PEoU). However, this theory focuses only on the determinants of intention and does not tell us how such perceptions are formed or how they can be manipulated to foster user's acceptance and increased usage.

About TPB (Ajzen, 1991), beside of determinants of behavioral attitude and subjective norm, a third element, perceived behavioral control (PBC), also influences behavioral intentions and actual behavior. TPB was proposed as an extension of TRA to account for conditions where individuals do not have complete control over their behavior (Ajzen, 1991). In the practice, TPB have been applied to explain different types of behavior, and when applied to the adoption of ICT systems or services, the model contains five concepts which are behavioral attitudes, subjective norm, behavioral control, intention to use and actual use.

\subsection{Previous research on internet banking using TAM and TPB}

Foley and Jayawardhena (2000) stated that internet banking brings advantages to commercial banks as cost saving, reaching customers all the world, making banking services more flexible and easy to use. In addition to, commercial banks can implement new business strategies and enhance banks' performance and efficiency.

Sheshunoff (2000) opined that when bank's customers use a new technology transactions, for example, 
internet banking, they save both money and time by avoiding long queues at banks and they can conduct necessary transactions at anytime and anywhere. These new - tech transactions will bring competitive advantages for commercial banks and help them maintain their market share.

In studying the factors that influence the adoption of mobile banking in Kenya, Lule et al., (2012) used TAM and structural equation modeling to validate the research model. This study's results showed that perceived ease of use, perceived usefulness, perceived efficacy, and perceived credibility significantly influenced customers' attitude towards the use of mobile banking.

Toan et al., (2018) used TAM to explore factors that impact the intention of Vietnamese banks and their clients toward adopting internet banking services. In this study, internet banking was used to describe banking transactions via mobile, tablet apps and ATM. They found out that in the concrete condition of Vietnam, the adoption of using internet banking could be stimulated by perceived usefulness, perceived ease of use, and finally consumer satisfaction.

In the research of Alsamydai (2014) about the use of mobile banking services in Jordan. In his study, TAM was modified by introducing two new dimensions, quality and experience, to the five dimensions of TAM, which was introduced by Davis (1986). The results showed a positive correlation between all of these components and demonstrated the strong correlation between the attitude, perceived ease of use and experience toward the use of mobile banking services.

Lee, H. e al (2000) studied the determinants of perceived service quality and its relationship with satisfaction in Korea. The numbers of respondents interviewed were 197 for the aerobic school, 128 for the investment consult firms, and 196 for the entertainment park. The study's results found out that service quality is an antecedent of customer satisfaction and customer satisfaction creates a stronger influence on purchase intention than service quality. This thing can be that customers don't necessary to purchase the highest quality services and they may buy services providing more satisfaction.

Sukkar and Hasan (2005) considered the appropriateness of TAM in the developing countries and further they modified in the TAM for creating it more aggregate for developing countries.

Cheng et al., (2006) based on TAM with an added construct, perceived web security, to investigate how customers perceive and adopt internet banking in Hong Kong. The authors tested ability in predicting customers' behavioral intention of adopting internet banking. Using questionnaires to survey with randomly selected sample of customers using internet banking from the Yellow Pages, and obtained 203 usable responses. The authors used Structural Equation Modeling (SEM) to evaluate the magnitude of the hypothesized relationships. The results supported the extended TAM and confirm its robustness in predicting the intention of adoption of internet banking of Hong Kong customers.

Nasri, W. and Charfeddine, L., (2012) studied factors affecting the adoption of internet banking by Tunisian bank customers. The study integrated TAM and TPB. The model employed security and privacy, government support, self - efficacy and technology support, in addition to social norm, attitude, perceived ease of use, perceived usefulness, perceived behavior control and intention to use internet banking. Structural equation modelling was employed to investigate the inter - correlations among the constructs. The study's results confirmed the applicability of the TAM and TPB in predicting intention of using internet banking by Tunisian bank customers.

Yadav et al., (2014) combined the TPB and TAM theories with an additional construct that is perceived risk. The study was conducted with 210 young consumers in India. The results of this proposed conceptual framework successfully predicted the consumer's intention in adopting internet banking. The determinants as perceived usefulness, attitude, subjective norm and perceived behavioral control significantly influence the consumer's intention to adopt internet banking, whereas a non - significant positive relationship was found between perceived risk and consumer's intention to adopt internet banking which reveals that consumers still think usage of internet banking as a risky affair.

Generally speaking, there were the previous studies applied TAM (Suh and Han, 2003; Sukkar and Hasan, 2005; Pikkaraimen et al., 2004; Cheng et al., 2006; Celik, 2008; Toan et al., 2017) to investigate the consumer's intention to use internet banking. Those studies indicate the applicability of TAM in researching about intention of using internet banking services, as the TAM's variables were found to have a direct significant influence in adopting internet banking. Meanwhile, few researches have also integrated the TAM and TPB model to predict the 
customer's intention toward internet banking (Nasri and Charfeddine, 2012; Lee, 2009; Yadav, 2014) and these results support integrating of the variables of TAM and TPB. Some other studies have also done comparisons between TRA, TAM and TPB (Rouibah et al., 2009; Yousafzai et al., 2010).

\section{Research methodology}

In terms of data collection and sample, Hair et al. (2013, 2014) supported the convenience sampling method in collecting research data and Martins (2014) stated that the convenience sampling method can bring responses in a cost-effective way. Therefore, the convenience sampling method is used in this study, the investigated individual customers own smartphones and tablet apps and they can implement banking transactions via mobile, ATM, and tablet apps. The constructs and the indicators of this study are shown in Appendix 1. The five-point Likert scale was used in the questionnaire (SD - strongly disagree, D - disagree, $\mathrm{N}$ - neutral, $\mathrm{A}$ - agree, SA - strongly agree) to collect primary data. Prior to data collection, a pilot survey was conducted and further some refinements were made in the questions, based on the recommendations of pilot survey. Before carrying out a survey, a pilot test of survey was made and further some refinements were received in the questions; after adjusting questionnaire to ensure that questions reflected accurate information and confirm certain the objectives in data collection. The responders' demographic characteristics are provided in Appendix 2. The survey was made from July 2019 to February 2020 in the Central Region of Vietnam with 500 customers responded. Among the 500 individual customers, some use internet banking and some do not. The percentage of users and non-users of internet banking is depicted in Appendix 3.

Collected data were analysed by using PLS-SEM (Partial least squares-structural equation modeling). PLS-SEM generally permits to more flexibility in terms of data requirements and the specification of relationships between constructs and indicator variables (Sarstedt et al., 2017) and PLS-SEM relies on a bootstrap procedure to test coefficients for their significance (Davison, Hinkley, 1997). This study uses reflective measurement model, it includes seven constructs: Customer Service, Perceived Ease of Use, Perceived Usefulness, Customer Satisfaction, Subjective Norm, Perceived Behavior Control and Intention to Adopt (Figure 1). The study anticipates the following hypotheses:

$\mathrm{H}_{1}$ : Perceived Ease of Use has positive influence on Customer Satisfaction.

$\mathrm{H}_{2}$ : Perceived Ease of Use has positive influence on Perceived Usefulness.

$\mathrm{H}_{3}$ : Perceived Usefulness has positive influence on Customer Satisfaction.

$\mathrm{H}_{4}$ : Customer Service has positive influence on Customer Satisfaction.

$\mathrm{H}_{5}$ : Perceived Behavior Control has positive influence on Intention to Adopt.

$\mathrm{H}_{6}$ : Subjective Norm has positive influence on Intention to Adopt.

$\mathrm{H}_{7}$ : Customer Satisfaction has positive influence on Intention to Adopt.

$\mathrm{H}_{8}$ : Perceived Ease of Use indirectly affects to Intention to Adopt via Customer Satisfaction.

$\mathrm{H}_{9}$ : Perceived Usefulness indirectly affects to Intention to Adopt via Customer Satisfaction.

$\mathrm{H}_{10}$ : Customer Service indirectly affects to Intention to Adopt via Customer Satisfaction.

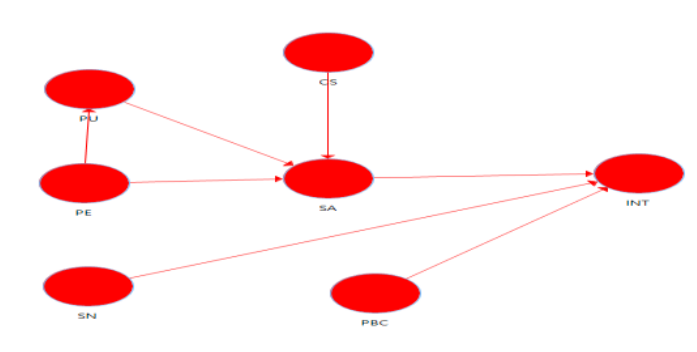

Figure 1: Theoretical Framework

\section{Results}

Outer loading of the indicators and average variance validity (AVE) were used to evaluate the convergent validity of the reflective constructs.

\subsection{Outer loading, Composite Reliability}

The outer loadings of all indicators should be statistically significant and the standardized outer loading should be above 0.70 . The measurement model has 31 indicators, but $\mathrm{PBC} 2, \mathrm{PBC} 3$ and PU2 indicators were eliminated because their outer loadings are smaller than 0.70 (Table 1). The square of a standardized indicator's outer loading represents how much variation in an item is explained by the construct and is described as the variance extracted from the item. 
Latent variable should explain a substantial part of each indicator's variance, usually at least $50 \%$, this means that an indicator's outer loading should be above 0.708 - based on the square of that number $\left(0.708^{2}=0.50\right)$ (Henseler et al., 2009). $\mathrm{R}^{2}$ value of $0.75,0.50$, or 0.25 for endogenous latent variables can be respectively described a substantial, moderate, or weak (Henseler et al., 2009).

Table 1: Outer Loadings

\begin{tabular}{|c|c|c|c|c|c|c|c|}
\hline & CS & INT & PBC & PE & PU & SA & SN \\
\hline CS1 & 0.795 & & & & & & \\
\hline CS2 & 0.779 & & & & & & \\
\hline CS3 & 0.764 & & & & & & \\
\hline CS4 & 0.755 & & & & & & \\
\hline INT1 & & 0.878 & & & & & \\
\hline INT2 & & 0.862 & & & & & \\
\hline INT3 & & 0.789 & & & & & \\
\hline INT4 & & 0.854 & & & & & \\
\hline PBC1 & & & 0.782 & & & & \\
\hline PBC4 & & & 0.916 & & & & \\
\hline PE1 & & & & 0.820 & & & \\
\hline PE2 & & & & 0.817 & & & \\
\hline PE3 & & & & 0.838 & & & \\
\hline PE4 & & & & 0.762 & & & \\
\hline PE5 & & & & 0.768 & & & \\
\hline PU1 & & & & & 0.777 & & \\
\hline PU3 & & & & & 0.768 & & \\
\hline PU4 & & & & & 0.743 & & \\
\hline PU5 & & & & & 0.755 & & \\
\hline SA1 & & & & & & 0.842 & \\
\hline SA2 & & & & & & 0.740 & \\
\hline SA3 & & & & & & 0.739 & \\
\hline SA4 & & & & & & 0.836 & \\
\hline SN1 & & & & & & & 0.789 \\
\hline SN2 & & & & & & 0.783 \\
\hline SN3 & & & & & & & 0.721 \\
\hline SN4 & & & & & & & 0.758 \\
\hline SN5 & & & & & & 0.734 \\
\hline
\end{tabular}

Source: Compiled by the authors

Composite Reliability: Cronbach's Alpha is often used to estimate reliability based on the intercorrelations of the observed indicator variables. Cronbach's Alpha assumes that all indicators are equally reliable, but PLS-SEM prioritizes the indicators according to their individual reliability and moreover Cronbach's Alpha is sensitive to the number of the items in the sample and generally tends to underestimate the internal consistency reliability. Hence, in this study, a different measure of internal consistency reliability can be used, it is Composite Reliability (Hair et al., 2017). The composite reliability (CR) method depicts the degree to which the construct indicators represent the latent constructs. With a value of 0.856 (Customer Service), 0.900 (Perceived Ease of Use), 0.846 (Perceived Usefulness), 0.869 (Satisfaction), 0.840 (Perceived
Behavior Control), 0.870 (Subjective Norm) and 0.910 (Intention to Adopt), all seven reflective constructs have a high level of internal consistency reliability (Table 2).

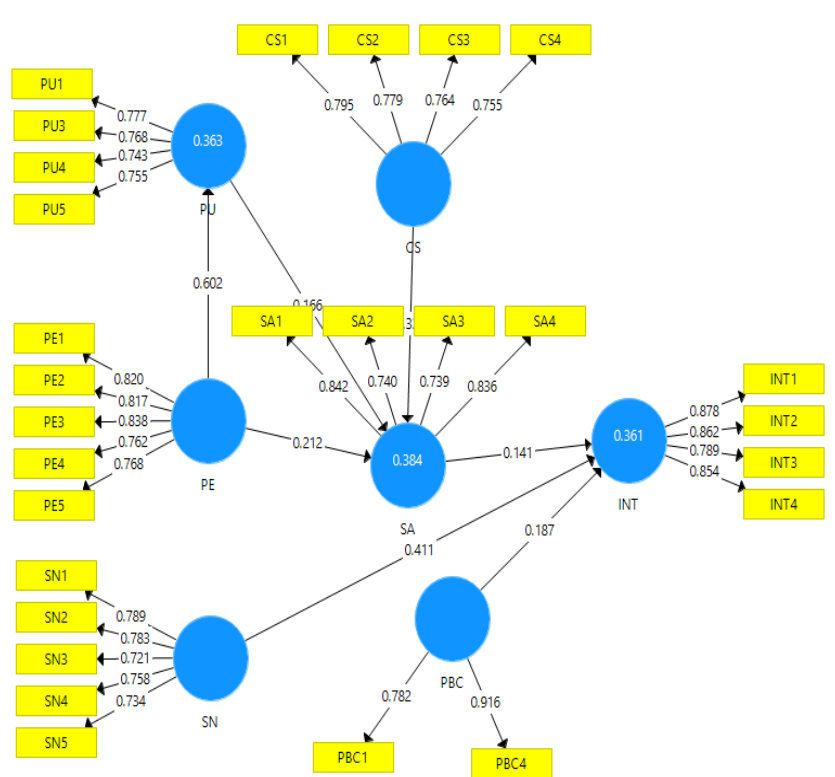

Figure 2: Measurement Model.

\subsection{Discriminant validity}

Discriminant validity is the extent in which a construct is truly distinct from other constructs by empirical standards. Average variance extracted (AVE) is often used. An AVE value of 0.50 or higher is accepted, which means that the construct explains more than half of the variance of its indicators. AVE values of seven constructs are larger than 0.50, therefore the research model gains the discriminant validity (Hair et al., 2017). (Table 2)

Table 2: Construct Reliability and Validity

\begin{tabular}{|c|c|c|c|}
\hline & $\begin{array}{c}\text { Cronbach's } \\
\text { Alpha }\end{array}$ & $\begin{array}{c}\text { Composite } \\
\text { Reliability }\end{array}$ & $\begin{array}{c}\text { Average } \\
\text { Variance } \\
\text { Extracted } \\
\text { (AVE) }\end{array}$ \\
\hline CS & 0.776 & 0.856 & 0.598 \\
\hline INT & 0.868 & 0.910 & 0.717 \\
\hline PBC & 0.637 & 0.840 & 0.726 \\
\hline PE & 0.861 & 0.900 & 0.642 \\
\hline PU & 0.758 & 0.846 & 0.579 \\
\hline SA & 0.801 & 0.869 & 0.626 \\
\hline SN & 0.815 & 0.870 & 0.574 \\
\hline
\end{tabular}

Source: Compiled by the authors

\subsection{R- Square}

The R-Square values are shown inside the blue ellipse for endogenous latent variables (Figure 2). For the endogenous variable Intention to Adopt, the R- 
Square value is 0.361 , meaning that about $36.10 \%$ of the variance in Intention to Adopt internet banking is explained by the model (Table 3); this is a moderate level.

Table 3: R - Square

\begin{tabular}{|c|c|c|}
\hline & R Square & R Square Adjusted \\
\hline INT & 0.361 & 0.358 \\
\hline PU & 0.363 & 0.361 \\
\hline SA & 0.384 & 0.380 \\
\hline
\end{tabular}

Source: Compiled by the authors

\subsection{Inner Variance Inflation Factor (VIF) Value}

Collinearity occurs when two variables that are hypothesized to be causally related measure the same construct. Values of VIF 3.3 or higher indicate potential collinearity (Diamantopoulos and Siguaw, 2006). According to the results in Table 4, Customer Service has the highest inner VIF value (2.005), hence, inner VIF values are uniformly below the threshold value of $5 \%$.

Table 4: Inner VIF Values

\begin{tabular}{|c|c|c|c|c|c|c|c|}
\hline & CS & INT & PBC & PE & PU & SA & SN \\
\hline CS & & & & & & 2.055 & \\
\hline INT & & & & & & & \\
\hline PBC & & 1.282 & & & & & \\
\hline PE & & & & & 1.000 & 1.786 & \\
\hline PU & & & & & & 2.026 & \\
\hline SA & & 1.532 & & & & & \\
\hline SN & & 1.401 & & & & & \\
\hline
\end{tabular}

Source: Compiled by the authors

\subsection{Hypothesis Testing}

The bootstrapping procedure was used to assess the significance and relevance of the structural model relationships (Figure 3).

Commonly used critical values for two-tailed tests are 1.65 (significance level=10\%), 1.96 (significance level $=5 \%$ ), and 2.57 (significance level=1\%) (Hair, 2017). The results in Table 5 depict the path coefficients of the respective constructs with their level of significance in order to validate some of the considered hypotheses.

The relationship between PE and PU is accepted by $\mathrm{H}_{1}$ : (t-statistic $\left.=19.300, \mathrm{p}=0.000\right)$. Hereafter, the relationship between $\mathrm{PE}$ and $\mathrm{SA}$ is admitted by $\mathrm{H}_{2}(\mathrm{t}-$ statistic $=4.178, \mathrm{p}=0.000) . \mathrm{H}_{3}$ showed that $\mathrm{PU}$ is positively related to $\mathrm{SA}(\mathrm{t}$-statistic $=3.432, \mathrm{p}=0.001)$. Following, the relationship between CS and SA is accepted by $\mathrm{H}_{4}$ : ( $\mathrm{t}$-statistic $\left.=7.077, \mathrm{p}=0.000\right)$. The relationship between $\mathrm{PBC}$ and INT is complied by $\mathrm{H}_{5}$ : (t-statistic $=4.640, \mathrm{p}=0.000)$, and $\mathrm{H}_{6}$ is accepted ( $\mathrm{t}$ statistic $=9.815, \mathrm{p}=0.000)$. Meanwhile, $\mathrm{H}_{7}$ about the relationship between SA and INT is also supported ( $\mathrm{t}-$ statistic $=3.169, \mathrm{p}=0.002$ ).

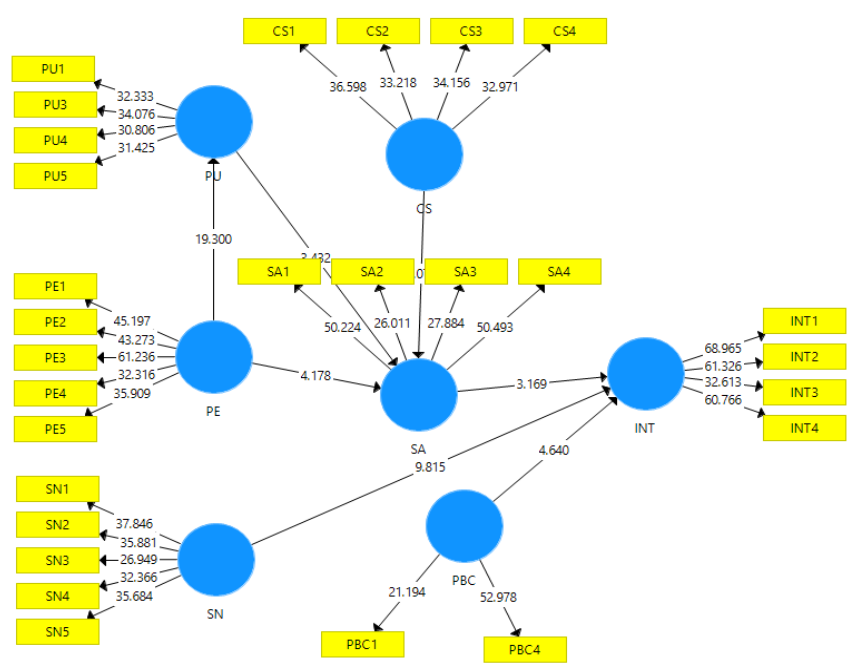

Figure 3: Bootstrapping Procedure

Table 5: Path Coefficients Mean, STDEV, T-Values, P-Values

\begin{tabular}{|c|c|c|c|c|c|c|}
\hline Hypothesis & Relationship & $\begin{array}{l}\text { Original } \\
\text { Sample } \\
\text { (O) }\end{array}$ & $\begin{array}{l}\text { Sample } \\
\text { Mean } \\
\text { (M) }\end{array}$ & $\begin{array}{c}\text { Standard } \\
\text { Deviation } \\
\text { (STDEV) }\end{array}$ & $\begin{array}{c}\text { T Statistics } \\
(|\mathrm{O} / \mathrm{STDEV}|)\end{array}$ & $\begin{array}{c}\mathrm{P} \\
\text { Values }\end{array}$ \\
\hline H1 & $\mathrm{PE} \rightarrow \mathrm{PU}$ & 0.602 & 0.603 & 0.031 & 19.300 & 0.000 \\
\hline $\mathrm{H} 2$ & $\mathrm{PE} \rightarrow \mathrm{SA}$ & 0.212 & 0.212 & 0.051 & 4.178 & 0.000 \\
\hline H3 & $\mathrm{PU} \rightarrow \mathrm{SA}$ & 0.166 & 0.168 & 0.048 & 3.432 & 0.001 \\
\hline $\mathrm{H} 4$ & $\mathrm{CS} \rightarrow \mathrm{SA}$ & 0.331 & 0.332 & 0.047 & 7.077 & 0.000 \\
\hline H5 & $\mathrm{PBC} \rightarrow \mathrm{INT}$ & 0.187 & 0.168 & 0.040 & 4.640 & 0.000 \\
\hline H6 & $\mathrm{SN} \rightarrow \mathrm{INT}$ & 0.411 & 0.413 & 0.042 & 9.815 & 0.000 \\
\hline $\mathrm{H} 7$ & $\mathrm{SA} \rightarrow \mathrm{INT}$ & 0.141 & 0.140 & 0.044 & 3.169 & 0.002 \\
\hline
\end{tabular}

Source: Compiled by the authors

\subsection{Mediation Analysis}

Mediation occurs when a third mediator variable intervenes between two other related constructs (Hair, 2017). More precisely, a change in the exogenous construct causes a change in the mediator variable, which, in turn, results in a change in the endogenous construct in the PLS path model. This study analyzes the significance of the indirect effect of Customer Service on Intention to Adopt via the mediator variable (Customer Satisfaction). If the indirect effect is significant, we conclude that Customer Satisfaction gets function as a mediator in the tested relationship. From Figure 3 and Table 6, it follows that PU serves as mediator variable in the relationship between PE and SA. At the same, SA as mediator variable in the 
relationship between PU and INT, between CS and INT, between PE and INT. From the aforementioned results, hypothesis $\mathrm{H}_{8}, \mathrm{H}_{9}$ and $\mathrm{H}_{10}$ are accepted.

Table 6: Specific Indirect Effects

Mean, STDEV, T-Values, P-Values

\begin{tabular}{|l|c|c|r|r|r|}
\hline & $\begin{array}{c}\text { Original } \\
\text { Sample } \\
(\mathrm{O})\end{array}$ & $\begin{array}{c}\text { Sample } \\
\text { Mean } \\
(\mathrm{M})\end{array}$ & $\begin{array}{c}\text { Standard } \\
\text { Deviation } \\
(\mathrm{STDEV})\end{array}$ & $\begin{array}{c}\text { T Statistics } \\
(\mid \mathrm{O} / \text { STDEV } \mid)\end{array}$ & $\begin{array}{c}\mathrm{P} \\
\text { Values }\end{array}$ \\
\hline $\mathrm{CS} \rightarrow \mathrm{SA} \rightarrow \mathrm{INT}$ & 0.047 & 0.046 & 0.015 & 3.027 & 0.002 \\
\hline $\mathrm{PE} \rightarrow \mathrm{SA} \rightarrow \mathrm{INT}$ & 0.030 & 0.030 & 0.013 & 2.306 & 0.021 \\
\hline $\mathrm{PU} \rightarrow \mathrm{SA} \rightarrow \mathrm{INT}$ & 0.023 & 0.024 & 0.011 & 2.166 & 0.030 \\
\hline $\mathrm{PE} \rightarrow \mathrm{PU} \rightarrow \mathrm{SA} \rightarrow \mathrm{INT}$ & 0.014 & 0.014 & 0.007 & 2.118 & 0.034 \\
\hline $\mathrm{PE} \rightarrow \mathrm{PU} \rightarrow \mathrm{SA}$ & 0.100 & 0.101 & 0.030 & 3.295 & 0.001 \\
\hline
\end{tabular}

Thus, the results of proposed hypothesis revealed that, all ten hypotheses have significant relationships with their respective endogenous variables.

\subsection{Importance Performance Matrix Analysis (IPMA)}

The IPMA compares the structural model's total effects on a specific target construct (INT $=$ Intention to Adopt) with the average latent variable scores of this construct's predecessors (PE, PU, CS, SN, PBC, SA).

The total effects represent the predecessor constructs' importance in shaping the Intention to Adopt while their average latent variable scores represent their performance. The goal is to identify the predecessors that have relatively high importance for INT but also a relatively low performance

The aspects underlying these constructs represent a potential area for improvement that may be of interest. Using the IPMA data allows us to create an important performance map as shown in Figure 4. The $\mathrm{X}$-axis represents the (unstandardized) total effects of PE, PU, CS, SN, PBC, SA on the target construct INT. The y-axis depicts the average rescaled (unstandardized) latent variable scores of PE, PU, CS, PBC, SN and SA.

Figure 4 shows the index values and total effect scores. It can be seen that Subjective Norm is the most important factor in determining the Intention to Adopt internet banking due to its higher importance values compared to other latent variables. IPM (Figure 4) showed that Subjective Norm has the highest potential to influence customers considering the adoption of internet banking, Perceived Behavior Control and Customer Satisfaction also are the important factors. In other words, the managers of commercial banks need to focus on improving the performance of subjective norm, customer satisfaction, and the perceived behavior control.

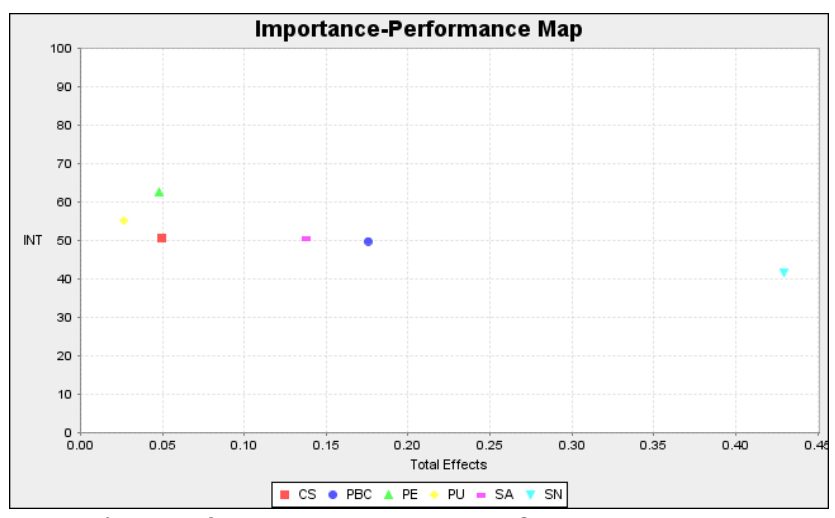

Figure 4: Importance-Performance Map

\section{Conclusion}

The findings show that the intention to adopt internet banking in Vietnam can be predicted by perceived ease to use, perceived usefulness, customer service, customer satisfaction, subjective norm and perceived behavior control; in which subjective norm, perceived behavior control and customer satisfaction have strong influence to the intention to adopt internet banking.

The empirical results also show that the integration of TAM and TPB has good explanatory power, to provide a comprehensive model to enhance knowledge on the antecedents of internet banking adoption in Vietnam emerging economy.

The results show that the proposed model has a good explanatory power and confirms its robustness in predicting customers' intentions to adopt Internet banking. The study broadens and deepens understandings of factors contributing to the development of internet banking, especially for an emerging country such as Vietnam.

\section{Recommendation}

This study provides useful insights to point out potential implications for developing internet banking in Vietnam:

First, understanding the potent effects of variables investigated, banks should encourage the existing customers who have not used e-banking service yet to access and attract new customers to use e-banking service by providing clearly its functions and outstanding benefits. Besides, banks can organize workshops and customer conferences to introduce e- 
banking product and internet banking service to provide customers with knowledge required for effectively using these services. Banks should also understand customers' opinions, their expectations as well as their requirements, thus by, banks effectively invest in advertising and marketing campaigns with trust images of customers to create a positive impact on those who customers respect as their relatives, colleagues, and their friends ..., and to build beliefs, then, to create demand for e-banking service.

Meantime, advertisements could be linked to celebrity endorsements, influencer affiliations at prestigious events with prestigious figures to enhance awareness of using e-banking service. Thereby, banks can multiply the number of customers using the service and increase the number of loyal customers.

Second, the concept of internet banking should be effectively communicated as consumers perceive about the usefulness of internet banking. Banks should widely announce advantages of online banking and internet banking in comparison with traditional services, for instance, its opportunities to save both time and money... In addition, banks should invest in technology to make them easy to use, the easy-to-use interface to guide new customers' needs be a simple and clear instruction

Third, banks should focus on keeping opening specialized training courses for employees in charge of e-banking service operations, to ensure that these employees are well-trained with updated knowledge to keep up with latest technology and good skills to answer customers' questions faster and most accurately. Banks also need to pay attention to the distribution of human resource and allocate rationally for many business to make more profits (Bao. et al., 2020).

Fourth, banks need to invest in upgrading the server system and expanding the wide bandwidth, high capacity, and high speed transmission line, which supports banks to enhance the efficiency of transmitting and processing information on the network as well as minimizing the network congestion which affects the service quality.

Commercial banks should also ensure that security and privacy of the internet banking systems are properly developed, thereby, their systems are aware to be safe, secured. Users, then, can believe that their personal and financial information are protected. These problems may create a favorable image in the society, leading to a higher intention towards internet banking among consumers in Vietnam.
Fifth, The Vietnamese government should play an essential role in issuing a legal framework for internet banking and e-banking services; especially in promptly preventing and stopping crime to ensure the information security, reduce risks, and to protect customers' interests. Furthermore, the Vietnamese government should also build regulations to promote non-cash payments during the period of 2021-2025 and develop e-government regulations to enhance the use of banking services. In particular, $80 \%$ of tax payments in cities are to be made via banks by 2022 . Other strategic targets are presented in Table 7.

Table 7: Strategic Targets for the Development of the Banking Sector in Vietnam

\begin{tabular}{|c|c|c|c|}
\hline $\begin{array}{c}\text { Planning } \\
\text { horizon }\end{array}$ & $\begin{array}{c}\text { Type of } \\
\text { payments } \\
\text { accepted via } \\
\text { banks }\end{array}$ & $\begin{array}{c}\text { Service } \\
\text { providers } \\
\text { (target share) }\end{array}$ & $\begin{array}{c}\text { Service } \\
\text { Consumers } \\
\text { (target share) }\end{array}$ \\
\hline 2021 & $\begin{array}{c}\text { Power and } \\
\text { water } \\
\text { bill payments }\end{array}$ & $\begin{array}{c}\text { Suppliers } \\
(80 \%)\end{array}$ & $\begin{array}{c}\text { Households } \\
\text { in large cities } \\
(30 \%)\end{array}$ \\
\hline 2023 & Tuition fees & $\begin{array}{c}\text { Colleges and } \\
\text { Universities } \\
(100 \%)\end{array}$ & Students (70\%) \\
\hline 2025 & $\begin{array}{c}\text { Eating, room } \\
\text { for rent }\end{array}$ & $\begin{array}{c}\text { Restaurants, } \\
\text { hotels } \\
(80 \%)\end{array}$ & $\begin{array}{c}\text { Customers in } \\
\text { large city } \\
(40 \%)\end{array}$ \\
\hline
\end{tabular}

Source: Compiled by the authors

Last, the development of e-commerce should be significantly investigated. To encourage and increase the number of customers using e-banking, business, supermarkets, shopping malls, stores and restaurants need to be equipped with devices for implementing non-cash payments. Besides, cooperative and affiliated relationships with insurance companies, car dealers, supermarkets, amusement parks, entertainment areas, tourist destination spots...should be extended. Moreover, banks need to expand the network of e-banking customers towards individual customers who open payment account, retired officials, soldiers, and students.

\section{Notes}

${ }^{(1)}$ Internet World Stats, Usage and Population Statistics, 2018.

Available at: http://www.internetworldstatistic.com.

${ }^{(2)}$ Quyen D.V. (2018). E-commer: Much room left for growth. The Saigom Time, No 13 (1381), March 24, 2018

(3) Vietnam eCommerce and Digital Economy Agency. Ministry of Industry and Trade.

Available at: http://en.idea.gov.vn/default.aspx?page $=$ news $\& d o=d$ 
etail\&category $\mathrm{id}=4 \mathrm{f} 89 \mathrm{e} 92 \mathrm{~d}-\mathrm{e} 344-49 \mathrm{f6}-9 \mathrm{abc}-$

0ffa134f88a1\&id=ed56a28c-98af-4318-bd32-

3da1b4119f31

References:

[1] Ajzen.I., and M. Fishbein. (1980). Understanding Attitudes and Predicting Social Behavior: Englewood Cliffs, NJ: Prentice Hill.

[2] Ajzen, I., (1991). The theory of planned behavior, Organization Behavior and Human Decision Process, Vol. 50 No. 2, pp. 179-211.

[3] Alsamydai M.J. (2014). Adaptation of the TAM to the use of mobile banking services. International Review of Management and Business Research, Vol. 3 No 4, pp. 2016-2028.

[4] Akinci, S., Aksoy, S. and Atilgan, E. (2004). Adoption of internet banking among sophisticated consumer segments in an advanced developing country, International Journal of Bank Marketing, Vol. 22 No. 3, pp. 212-232.

[5] Bao, G., Zeng, F., and Wang, M., (2020). Study on human resource allocation efficiency based on DEA analysis, International Journal of Circuits, Systems and Signal Processing, Vol. 14 , pp. 826-832

[6] Blut M. (2016). E-Service Quality: Development of a Hierarchical Model. Journal of Retailing, Vol. 92 No 4, pp. 500-517.

[7] Bryman A.B. (2007). Business Research Methods, Oxford: Oxford University Press.

[8] Celik, H. (2008). What determines Turkish customers' acceptance of internet banking?, International Journal of Bank Marketing, Vol. 26 No. 5, pp. 353-370.

[9] Cheng, T.C., Lam, D.Y. and Yeung, A.C. (2006). Adoption of internet banking: an empirical study in Hong Kong, Decision Support Systems, Vol. 42 No. 3, pp. 1558-1572.

[10] Cohen J. (1988). Statistical power analysis for the behavioral sciences ( $2^{\text {nd }}$ ed.), Hillside Mahwah, NJ: Lawrence Erlbaum.

[11] Davis F.D. (1986). A technology acceptance model for empirically testing new end-user information systems: Theory and results, Cambridge, MA: Massachusetts Institute of Technology.

[12] Davis F.D. (1989). Perceived usefulness, perceived ease of use and user acceptance of information technology. MIS Quarterly, Vol. 13 No 3, pp. 319-340.
[13] Davison A.C. (1997). Hinkey D.V, Bootstrap methods and their application, Cambridge, UK: Cambridge University Press.

[14] Diamantopoulos A., Siguaw J.A. (2006). Formative versus reflective indicators in measure development: Does the choice of indicators matter? British Journal of Management, Vol. 17 No 4, pp. 263-282.

[15] Foley P., Jayawardhena C. (2000). Changes in the banking sector-the case of Internet banking in the UK. Internet Research, Vol. 10 No 1, pp. 1930.

[16] Hair J.F., Hult G.T., Ringle C.M., Sarstedt M. (2017). A primer on partial least squares structural equation modeling (2nd ed.), Thousand Oaks, CA: SAGE Publications.

[17] Hair J.F., Hult G.T.M., Ringle C., Sarstedt M. (2013). A Primer on Partial Least Squares Structural Equation Modeling (PLS-SEM), Thousand Oaks, CA: SAGE Publications.

[18] Hair J.F., Sarstedt M., Hopkins L., Kuppelwieser G.V. (2014). Partial least squares structural equation modeling (PLS-SEM): An emerging tool in business research. European Business Review, Vol. 26 No 2, pp. 106-121.

[19] Henseler J., Ringle C.M., Sinkovics R.R. (2009). The use of partial least squares path modeling in international marketing. Advances in International Marketing, Vol. 20, pp. 277-320.

[20] Kannabiran, G. and Narayan, P.C. (2005), Deploying internet banking and e-commerce: case study of a private-sector bank in India, Information Technology for Development. 2005,Vol. 11 No. 4, pp. 363-379.

[21] Lee, M.C. (2009). Factors influencing the adoption of internet banking: an integration of TAM and TPB with perceived risk and perceived benefit, Electronic Commerce Research and Applications, Vol. 8 No. 3, pp. 130-141.

[22] Lee, H., Lee, Y. and Yoo, D. (2000). The determinants of perceived service quality and its relationship with satisfaction. International Journal of Bank Marketing, Vol. 14 No. 3, pp. $217-231$.

[23] Lule I., Omwansa T.K., Waema T.M. (2012). Application of Technology Acceptance Model (TAM) in M-Banking Adoption in Kenya. International Journal of Computing and ICT Research, Vol. 6 No 1, pp. 31-43.

[24] Martins C., Oliveira T., Popovie A. (2014). Understanding the Internet banking adoption: A 
unified theory of acceptance and use of technology and perceived risk application. International Journal of Information Management, Vol. 34 No 1, pp. 1-13.

[25] Meshref, H., (2020). Predicting loan approval of bank direct marketing data using ensemble machine learning algorithms, International Journal of Circuits, Systems and Signal Processing, Vol. 14, pp. 914-922.

[26] Nasri, W. and Charfeddine, L. (2012). Factors affecting the adoption of internet banking in Tunisia: an integration theory of acceptance model and theory of planned behavior, The Journal ofHish Technology Management Research, Vol. 23 No. 1, pp. 1-14.

[27] Pikkarainen K., Karjaluoto H., Pahnila S. (2004). Consumer acceptance of online banking: An extension of the technology acceptance model. Internet Research, Vol. 14 No 3, pp. 224-235.

[28] Quyen D.V. (2018). E-commerce: Much room left for growth. The Saigon Times, No 13 (1381), March 24.

[29] Rouibah, K., Thurasamy, R. and May, O.S. (2009). User acceptance of internet banking in Malaysia: test of three competing models, International Journal of E-Adoption, Vol. 1 No. 1, pp. 1-19.

[30] Sarstedt M., Ringle C.M., Hair J.F. (2017). Partial Least Squares Structural Equation Modeling. Handbook of Market Research (eds. C. Homburg, M. Klarmann, A. Vomberg), Heidelberg; New York; Dordrecht; London: Springer (print version forthcoming), DOI: 10.1007/978-3-319-05542-8 15-1. Available at: http://www.researchgate.net/publication/319669 432, accessed 02.05.2018.

[31] Sheshunoff A. (2000). Internet banking: An update from the frontlines. $A B A$ Banking Journal, Vol. 92 No 1, pp. 51-53.

[32] Suh, B. and Han I. (2003). Effect of trust on customer acceptance of internet banking, Electronic Commerce Research and Applications, Vol. 1 No. 3, pp. 247-263.

[33] Sukkar, A.A. and Hasan, H. (2005), Toward a model for the acceptance of internet banking in developing countries, Information Technology for Development. Vol. 11 No. 4, pp. 381-398.

[34] Toan, D. L., Phu, H. N., Nhan, V. H., Yen, T. P. H., Tam, Q. N., Anh, N.N. L. (2018). Technology Acceptance and Future of Internet
Banking in Vietnam. Foresight and STI Governance, Vol. 12 No. 2, pp. 36 - 49.

[35] Venkatesh V., Davis F.D. (2000). Theoretical extension of the technology acceptance model: Four longitudinal field studies. Management Science, Vol. 46 No 2, pp. 186-204.

[36] Yadav, R., Chauhan,V. and Pathak, G. (2015), Inention to adopt internet banking in an emerging economy: a perspective of Indian youth. International Journal of Bank Marketing, Vol. 33 No 4, pp. 530 - 544.

[37] Yousafzai, S.Y., Foxall, G.R. and Pallister, J.G. (2010). Explaining internet banking behavior: theory of reasoned action, theory of planned behavior, or technology acceptance model?, Journal of Applied Social Psychology, Vol. 40 No. 5, pp. 1172-1202.

\section{Creative Commons Attribution License 4.0 (Attribution 4.0 International, CC BY 4.0)}

This article is published under the terms of the Creative Commons Attribution License 4.0 https://creativecommons.org/licenses/by/4.0/deed.en US 